\title{
EFFECT OF EDUCATION AND TRAINING, CAREER DEVELOPMENT AND POSITION PLACEMENT ON PERFORMANCE OF EMPLOYEES ALMUSLIM UNIVERSITY BIREUEN DISTRICT
}

\author{
Mirza $^{1 *}$, Win Konadi') dan Mukhlis ${ }^{3)}$, \\ 1, Master of Management Student, Faculty of Economics and Business UNIKI \\ 2,3 Lecturers in Faculty of Economics Almuslim University - Bireuen \\ *) email: mirzastie@gmail.com
}

DOI:

https://doi.org/10.55178/idm.v1i1.208

ABSTRACT

Article history

Received:

March 7, 2020

Revised:

March 12, 2020

Accepted:

March 14, 2020

Page:

$13-25$

Keywords:

Training, Career

Development, Position

Placement, Performance
The study was conducted at the University of Almuslim Bireuen, with the aim to find out; 1) The Effect of Education and Training on Employee Performance, 2) The Effect of Career Development on Employee Performance, and 3) The Effect of Position Placement on Employee Performance. The research method used is descriptive and verification research. Data analysis with the path analysis model (Path Analysis). Descriptive research is research that aims to obtain a description of the training, career development, job placement and employee performance at Almuslim Bireuen University. While verification research basically wants to test the truth of a hypothesis that is carried out through data collection in the field. The sample studied was all employees of Almuslim University with 158 employees. The results of the analysis showed the influence of education and training factors on employee performance at Almuslim University, which amounted to $21.18 \%$. The results of the data analysis also prove the influence of Career Development factors on the performance of Almuslim University employees, which is equal to $20.99 \%$. And from the results of subsequent analysis, it shows that there is an influence of the Employee Position Placement factor on the Performance of Almuslim University employees, which is $14.27 \%$.

\section{Pendahuluan (Introduction)}

Perguruan Tinggi adalah tempat mencetak intelektual yang diharapkan mampu memberi perubahan pada diri pribadi maupun lingkungan di masyarakat. Melalui perannya dalam melaksanakan Tri Dharma Perguruan Tinggi yaitu melakukan pendidikan dan pengajaran, melakukan penelitian dan pengabdian kepada masyarakat. Semua kegiatan dalam Perguruan Tinggi harus didukung oleh sumber Daya Manusia yang profesional dan bermutu yaitu dosen dan karyawan harus mempunyai kompetensi sesuai bidangnya masing-masing dan salah satu Perguruan Tinggi yang turut mencerdaskan kehidupan bangsa adalah Unversitas Almuslim Bireuen Provinsi Aceh.

Hal ini sejalan dengan tujuan Pendidikan tinggi sebagaimana tercantum dalam pasal 2 Peraturan Pemerintah Nomor 60 tahun 1999 tentang Pendidikan Tinggi, yaitu: "(1) Menyiapkan peserta didik menjadi anggota masyarakat yang memiliki kemampuan akademik dan/atau profesional yang dapat menerapkan, mengembangkan dan/atau menciptakan ilmu pengetahuan, teknologi dan/atau kesenian; (2) Mengembangkan dan menyebarluaskan ilmu pengetahuan, teknologi dan/atau kesenian dan/atau mengupayakan penggunaannya untuk meningkatkan taraf kehidupan masyarakat dan memperkaya kebudayaan nasional".

Universitas Almuslim Peusangan, Bireuen - Provinsi Aceh merupakan salah satu perguruan tinggi swasta (PTS) yang berada di Kabupaten Bireuen, yang pada tahun 2018 lalu terpilih sebagai PTS terbaik di Aceh menurut penilaian Lembaga Layanan Pendidikan Tinggi (LLDIKTI). Universitas Almuslim Peusangan ini berdiri tahun 2003, dengan SK Menteri Pendidikan Nasional Republik Indonesia Nomor : 02/D/O/2003 yang merupakan perubahan bentuk dari Sekolah-sekolah Tinggi dan Akademi dalam lingkup Perguruan Tinggi Almuslim. Untuk mencapai tujuan dan sasran pengembangan Universitas Almuslim dapat mempertahakan prestasi di amsa depan, hal yang penting menjadi penekanan adalah peningkatan kemampuan karyawan baik di sisi akademiknya, ataupun non akademik sehingga pencitraan Universitas dapat di 
pertahankan di masyarakat. Seperti kemampuan karyawan dalam pelayanan akademik, kualifikasi SDM Karyawan, penempatan kerja karyawan, perkembangan karir, kebutuhan akan Diklat dalam mendukung pencapaian kinerja karyawan. Karena hal ini semua juga mempengaruhi kinerja karyawan.

Tujuan pengembangan karyawan melalui pendidikan dan pelatihan adalah untuk memperbaiki efektivitas kerja karyawan dalam mencapai hasil kerja yang telah ditetapkan. Kondisi tersebut di atas dapat dicapai melalui peningkatkan pengetahuan dan peningkatan ketrampilan karyawan. Peningkatan pengetahuan yang merupakan proses intelektual dapat dilaksanakan melalui pendidikan formal, kuliah, atau mengikuti pelatihan yang telah diprogramkan oleh Universitas Almuslim Peusangan Bireuen.

Peningkatan karier bagi karyawan melalui pendidikan dan penempatan sangat diperlukan karena ada jabatan tertentu yang memang harus didukung oleh pendidikan dan pelatihan seperti manajemen pengelolaan sumber daya manusia, pelatihan manajemen informasi, pengelola unit-unit dan pusat kegiatan mahasiswa, serta kemampuan operator dalam system pengelolaan perguruan tinggi yang selaras dan mumpuni.

Meskipun upaya-upaya pendidikan dan pelatihan telah dilaksanakan, namun sorotan dari pihak-pihak yang membutuhkan terhadap kinerja karyawan Universitas Almuslim menurut peneliti masih lemah, bahkan ada mahasiswa dan dosen yang membuat surat kaleng tentang keluhan terhadap karyawan melalui kotak saran yang telah disediakan oleh universitas.

Agar setiap karyawan dapat memiliki kinerja yang baik, maka sudah seharusnya setiap instansi/lembaga/ perusahaan memberikan pendidikan dan pelatihan kepada setiap karyawannya, minimal pekerjaan yang menjadi tanggungjawabnya. Dengan pendidikan dan pelatihan yang diberikan oleh lembaga kepada karyawan, maka akan dapat meningkatkan kemampuan karyawan menyelesaikan pekerjaan sehingga akan dapat meningkatkan prestasi kerja karyawan. Namun pendidikan dan pelatihan yang diberikan haruslah memiliki dampak bagi karyawan yang mengikutinya, hal ini akan dapat mendukung tercapainya hal- hal yang diinginkan oleh lembaga/organisasi, ketika pendidikan dan pelatihan dilakukan oleh lembaga/organisasi.

Pendidikan berkaitan dengan usaha untuk mempersiapkan calon tenaga kerja yang diperlukan oleh suatu instansi atau organisasi sehingga cara penekanannya pada kemampuan kognitif, afektif dan psikomotor. Dalam human resources development, nilai-nilai kompetensi seorang karyawan/pekerja dapat dipupuk melalui program pendidikan, pengembangan atau pelatihan yang berorientasi pada tuntutan kerja aktual dengan penekanan pada pengembangan skill, knowledge and ability yang secara signifikan akan dapat mernberikan standar pendalam sistem dan proses kerja yang diterapkan.

Pendidikan dengan berbagai programnya mernpunyai peranan penting dalam proses memperoleh dan meningkatkan kualitas kemampuan professional individu. Melalui pendidikan seseorang dipersiapkan untuk memiliki bekal agar siap mengetahui, mengenal dan mengembangkan metode berpikir secara sistematik agar dapat memecahkan masalah yang akan dihadapi dalam kehidupan dikemudian hari (Sedarmayanti, 2001:97). Juga apa yang ditekankan Bernardin \& Russell dalam Gomes (2000) menyatakan bahwa Pelatihan adalah setiap usaha untuk memperbaiki kinerja pekerja pada pekerjaan tertentu yang sedang menjadi tanggung jawabnya, atau satu pekerjaan yang ada kaitannya dengan pekerjaannya, Pelatihan lebih berkaitan dengan peningkatan ketrampilan karyawan/pekerja yang sudah menduduki suatu pekerjaan atau tugas tertentu sehingga lebih menekankan pada ketrampilan (skill). Yoder (Mangkunegara, 2000: 159) membedakan antara istilah pelatihan (training) dan pengembangan developing), dimana pelatihan ditujukan untuk pegawai pelaksana dan pengawas. Sedangkan pengembangan ditujukan untuk pegawai tingkat rnanajemen. Umar (2000), melihat perbedaan pelatihan dan pengembangan dari segi waktu, dimana pelatihan ditujukan pada kebutuhan saat ini untuk dapat menguasai berbagai ketrampilan dan teknik pelaksanaan kerja, sedangkan pengembangan bertujuan untuk datang. Program pendidikan dan pelatihan merupakan sarana pembinaan dan pengembangan karir, melalui keikutsertaan dalam program pendidikan dan pelatihan, pegawai atau karyawan terpilih secara sadar dan berencana dipersiapkan oleh organisasinya untuk menerima tanggung jawab pekerjaan yang berbeda (rotasi) dan atau kedudukan/jabatan yang lebih tinggi (promosi) pada waktu yang akan datang (future oriented), dan karenanya program pendidikan dan pelatihan merupakan salah satu investasi surnber daya manusia (human invesment) yang sangat berharga bagi setiap organisasi pemerintah (Lembaga Administrasi Negara, 2002). Penyelenggaraan pendidikan dan pelatihan merupakan salah satu upaya untuk meningkatkan kualitas sumber daya manusia sesuai dengan kebutuhan pekerjaan dalarn rangka meningkatkan sumber daya manusia pada setiap unit kerja juga akan berhubungan dengan hakikat pendidikan dan pelatihan.

Kinerja karyawan selain mendapatkan pendidikan dan pelatihan yang baik dan benar, juga tergantung kepada bagaimana lembaga/organisasi mengatur penempatan sumber daya manusia secara seimbang sesuai dengan tuntutan melalui penyeleksian yang dilakukan secara baik dan benar. Atau dengan kata lain bahwa, ketika pendidikan dan pelatihan telah dilakukan dengan benar, maka menempatkan SDM sesuian dengan 
kemampuan dan bidangnya juga menentukan Kinerja karyawan tersebut. Penempatan pada dasarya penugasan karyawan kepada pekerjaan yang sesuai dan atau pekerjaan barunya. Keputusan penempatan dilakukan oleh manajer.

Dalam meningkatkan prestasi kerja karyawan, pihak manajemen perusahaan atau organisasi juga harus dapat memperhatikan faktor-faktor yang mempengaruhi naik turunnya prestasi kerja ataupun kinerja karyawan. Salah satu kebijakan yang dapat mempengaruhi prestasi kerja karyawan adalah pengembangan karir dan penempatan kerja (Puspitasari, Djali, \& Pambelum, 2015). Menurut Agustini (2011) faktor yang mempengaruhi prestasi kerja karyawan yaitu kesesuaian bidang dan kemampuan karyawan dalam bekerja. Hal tersebut ditentukan dari pengembangan karir dan penempatan kerja karyawan. Ketika karyawan dikerjakan di bidang yang diketahui maka pengetahuan pekerjaan juga akan menghasilkan kinerja yang baik. Faktor yang mempengaruhi pengembangan karir adalah perlakuan yang adil dalam berkarir yaitu dengan melakukan pengembangan karir didasarkan dengan pertimbangan yang objektif.

Berdasarkan uraian di atas peneliti tertarik untuk menkaji ulang faktor yang berkaitan dengan kienrja karyawan, dengan judul "Pengaruh Pendidikan dan Pelatihan, Pengembangan Karier dan Penempatan Jabatan Terhadap Kinerja Karyawan Universitas Almuslim Bireuen".

\section{Tinjauan Literatur (Literature Review)}

\section{Hubungan antara Pendidikan dan Pelatihan (Diklat) terhadap Pengembangan Karir Karyawan}

Salah satu upaya strategis yang sangat menentukan untuk meningkatkan keberadaan dan kemampuan pegawai adalah program pendidikan dan pelatihan. Diklat merupakan upaya untuk mengembangkan Sumber Daya Manusia, terutama untuk mengembangkan kemampuan intelektual dan kepribadian manusia. Penggunaan istilah pendidikan dan pendidikan dalam suatu institusi biasanya disatukan menjadi "Diklat". (Notoatmodjo, 2003). Senada dengan itu, Sedarmayanti (2001:97), menyatakan "Pendidikan dengan berbagai program mernpunyai peranan penting dalam proses memperoleh dan meningkatkan kualitas kemampuan professional individu. Melalui pendidikan seseorang dipersiapkan untuk memiliki bekal agar siap mengetahui, mengenal dan mengembangkan metode berpikir secara sistematik agar dapat memecahkan masalah yang akan dihadapi dalam kehidupan dikemudian hari”.

Sedangan pelatihan, menurut Bernardin \& Russell dalam Gomes (2000) adalah setiap usaha untuk memperbaiki kinerja pekerja pada pekerjaan tertentu yang sedang menjadi tanggung jawabnya,atau satu pekerjaan yang ada kaitannya dengan pekerjaannya, Pelatihan lebih berkaitan dengan peningkatan ketrampilan karyawan/pekerja yang sudah menduduki suatu pekerjaan atau tugas tertentu sehingga lebih menekankan pada ketrampilan (skill).

Amiruddin dan Win $(2010 ; 4)$ menyatakan : "Kita sepakat, bahwa begitu eratnya hubungan dunia kerja dengan pelatihan, sehingga tidak seorangpun dapat mengatakan batas yang jelas antara kerja dan pelatihan, karena hakekatnya, sifat kerja itu sendiri terus menerus berevolusi, dan pelatihan merupakan faktor penting yang memberikan sumbangan dalam proses evolusi tersebut.

Jadi, program Diklat merupakan sarana pembinaan dan pengembangan karir, melalui keikutsertaan dalam program pendidikan dan pelatihan, pegawai terpilih secara sadar dan berencana dipersiapkan oleh organisasinya untuk menerima tanggung jawab pekerjaan yang berbeda (rotasi) dan atau kedudukan/jabatan yang lebih tinggi (promosi) pada waktu yang akan datang (future oriented), dan karena-nya program pendidikan dan pelatihan merupakan salah satu investasi SDM (human invesment) yang sangat berharga bagi setiap organisasi pemerintah (Lembaga Administrasi Negara, 2002).

Sebagaimana juga disebutkan oleh Hasibuan (2005:86), pendidikan dan pelatihan merupakan proses peningkatan keterampilan kerja baik tekhnis maupun manajerial. Pendidikan berorientasi pada teori, dilakukan dalam kelas, berlangsung lama dan biasanya menjawab why. Sedangkan pelatihan berorientasi di lapangan, berlangsung singkat dan menjawab how. Dan Nasution (2002) menyatakan bahwa pendidikan dan pelatihan yang dilakukan bagi pegawai baru adalah mengenal dan menguasi pekerjaannya sedangkan bagi pegawai lama adalah untuk meningkatkan hasil pekerjaan baik sekarang maupun di masa datang dan meningkatkan produktivitas kerja karyawan.

Metode pelatihan terbaik tergantung dari berbagai faktor. Berdasarkan penjelasan Veithzal Rivai (2011:225226), dalam melakukan pelatihan ada beberapa faktor yang mempengaruhi yaitu instruktur, peserta, materi (bahan), metode, tujuan pelatihan, dan lingkungan yang menunjang. Faktor-faktor yang perlu dipertimbangkan dalam pelatihan yaitu : 1) Efektivitas biaya, 2) Materi program yang dibutuhkan, 3) Prinsip-prinsip pembelajaran, 4) Ketepatan dan kesesuaian fasilitas, 5) Kemampuan dan preferensi peserta, dan 6) Kemampuan dan preferensi instruktur pelatihan. 
Ada beberapa dimensi dan indikator dalam pelatihan seperti dijelaskan oleh Mangkunegara (2011:57), Indikator-indikator pelatihan adalah 1) Instruktur , 2). Peserta, 3). Materi (sesuai tujuan, sesuai komponen peserta, Penetapan sasaran), 4). Metode, dan 5). Tujuan yaitu meningkatkan keterampilan peserta.

Hal ini juga diungkapkan oleh Thaif et al. (2015) indikator dari pendidikan dan pelatihan adalah sebagai berikut: 1) Instruktur diklat adalah salah satu yang telah dipercayakan untuk menjadi pendamping untuk memberikan materi diklat dan bertanggung jawab untuk membimbing peserta dalam kegiatan ini. 2).Metode diklat adalah metode dan pendekatan yang digunakan dalam pelaksanaan pendidikan dan pelatihan. 3) Waktu diklat adalah akumulasi waktu yang mengikuti pendidikan dan pelatihan karyawan dalam proses implementasi. 4) Manfaat diklat adalah hasil pendidikan dan pelatihan yang diperoleh baik secara konseptual dan praktis oleh karyawan. Dan dimensi dan Indikator pelatihan menurut Veithzal Rivai (2005 :256) adalah sebagai berikut: (1) Karir karyawan, (2) Pengetahuan, (3) Pendidikan sesuai kebutuhan, (4) Sikap dan (5) Perilaku.

Maka diklat berkaitan dengan karir karyawan nantinya. Karena menurut Fubri (Hasibuan, 2002) pengembangan karir adalah aktivitas yang membantu karyawan merencanakan masa depan karir mereka di perusahaan agar karyawan dan perusahaan dapat mengembangkan diri secara maksimum, sedangkan menurut Flippo (2001), pengembangan karir adalah suatu rangkaian kegiatan kerja yang terpisah tetapi berkaitan, yang memberikan kesinambungan dan arti dalam kehidupan seseorang. Pengembangan karir adalah kegiatan yang dilakukan untuk meningkatkan kemampuan dalam rangka mencapai suatu rencana karir (Handoko, 2003).

Untuk mengukur pengembangan karir menurut Muhammad Burlian (2005) menggunakan 3 (tiga) Indikator yaitu : 1). Peningkatan Kemampuan, yang menurut Alwi dalam Burhan (2005) ada 4 (empat) pendekatan yang digunakan dalam peningkatan kemampuan yaitu : Pendidikan Formal b. Penilaian Pekerjaan (Assessment), c. Pengalaman Jabatan, dan d. Hubungan interpersonal. 2). Kepuasan kerja, dan 3). Sikap dan perilaku karyawan terhadap pekerjaanya.

\section{Hubungan antara Pendidikan dan Pelatihan terhadap Penempatan Jabatan Kerja Karyawan}

Menurut Yuniarsih \& Suwatno (2016) dalam melakukan penempatan kerja hendaknya memperhatikan indikator antara lain pendidikan, pengetahuan kerja, keterampilan kerja, dan keahlian.

Kesesuaian penempatan pegawai dalam suatu perusahaan merupakan suatu hal yang penting karena sangat berpengaruh pada pencapaian tujuan yang di bangun oleh sebuah perusahaan tersebut. Oleh karenanya dalam penempatan pegawai harus tepat dan sesuai tuntutan pekerjaan dengan kualifikasi kemampuan dan profesionalismenya. Seseorang akan bekerja dengan baik dan berhasil apabila mengetahui dengan jelas posisinya dalam suatu perusahaan Kejelasan itu sangat penting artinya bagi setiap pegawai karena memungkinkan mengetahui peranan dan sumbangan pekerjaan terhadap pencapaian tujuan kerja secara keseluruhannya.

Penempatan jabatan Menurut Veithzal (2004:211) adalah "Penempatan adalah penugasan atau penugasan kembali seseorang karyawan kepada pekerjaan barunya. Keputusan penempatan lebih banyak dibuat oleh manajer lini, biasanya supervisor seorang karyawan dengan berkonsultasi menentukan penempatan karyawan dimasa yang akan datang". Sedangkan Sastrohadiwiryo (2002:162) menyatakan "Penempatan adalah proses pemberian tugas dan pekerjaan kepada tenaga kerja yang lulus seleksi untuk dilaksanakan sesuai ruang lingkup yang telah ditetapkan, serta mampu mempertanggung jawabkan segala resiko dan kemungkinan-kemungkinan yang terjadi atas tugas dan pekerjaan, wewenang serta tanggung jawab". Dan menurut Hasibuan (2005:63) "penempatan adalah penugasan seseorang untuk menduduku jabatan, menyelenggarakan fungsi, dan menjalankan aktivitas tertentu".

Adapun faktor-faktor yang harus dipertimbangkan dalam penempatan tenaga kerja, menurut Hasibuan (2005) adalah 1) Kinerja Akademik yang dimiliki tenaga kerja selama mengikuti pendidikan sebelumnya harus dipertimbangkan, 2) Pengalaman bekerja pada pekerjaan sejenis, perlu mendapat pertimbangan dalam penempatan tenaga kerja. 3) Kesehatan Fisik dan Mental, 4) Status Perkawinan, dan 5) Usia. Sedangkan menurut Sastrohadiwiryo (2002:162) menyatakan faktor-faktor yang perlu dipertimbangkan dalam penempatan adalah 1) Latar belakang pendidikan, 2) Kesehatan jasmani dan rohani, 3) Pengalaman kerja, 4) Umur sumber daya manusia, 5) Jenis kelamin, 6) Status perkawinan, dan 7) Minat dan hobi.

\section{Hubungan antara Pengembangan Karir terhadap Penempatan Jabatan Kerja Karyawan}

Pengembangan SDM / aparatur berbasis kompetensi, sangat diperlukan guna mewujudkan organisasi atau instansi pemerintahan yang profesional. Thoha (2008) menyatakan bahwa 'Pengembangan karier pegawai di daerah mempertimbangkan integritas dan moralitas, pendidikan dan pelatihan, pangkat, mutasi jabatan, 
mutasi antar daerah, dan kompetensi”. Sehinggga pengembangan karier erat hubungannya dengan kompetensi yang dimiliki seseorang dalam menjalankan tugasnya.

Seseorang akan bekerja secara berdayaguna dan berhasil guna apabila mengetahui dengan jelas posisinya dalam suatu organisasi kerja. Kejelasan itu sangat penting artinya bagi setiap pegawai karena memungkinkan mengetahui peranan dan sumbangan pekerjaan terhadap pencapaian tujuan kerja secara keseluruhannya. Hal-hal yang perlu diperhatikan dalam penempatan pegawai yaitu persyaratan kesesuaian antara minat, bakat, pengetahuan, keterampilan dan keahlian pegawai dengan jenis dan tingkat pekerjaan/ jabatan yang dipercayakan kepadanya. Dengan kata lain penempatan harus berpegang kepada prinsip the right man on the right place and the right man in the right job. Artinya pimpinan organisasi harus mampu memilih orang-orang yang memiliki kompetensi yang sesuai dengan tuntutan tugas dan tanggung jawab bagi pencapaian tugas pokok dan fungsi dari unit-unit dimana mereka akan ditempatkan.

Demi mencapai obyektifitas dan keadilan dalam pengangkatan, pemindahan dan pemberhentian dalam dan dari jabatan struktural, diperlukan penerapan nilai-nilai impersonal, keterbukaan, profesional dan penetapan persyaratan jabatan yang terukur bagi pegawai/Aparatur maupun jabatan yang akan didudukinya. Ketidaktepatan dalam penempatan pegawai membawa dampak pada kinerjanya dan kinerja organisasi karena penempatan yang salah akan menurunkan kinerja pegawai sehingga kinerja organisasi juga menurun. Selain itu, analisis jabatan dan analisis beban kerja belum dapat dilakukan secara menyeluruh dalam penempatan seorang pegawai pada unit organisasi sesuai dengan kebutuhan dan jabatan struktural tertentu berdasarkan keahlian.

Untuk meningkatkan kinerja pegawai, perlu adanya motivasi bagi para pegawai yang berpengaruh terhadap psikologis seorang pegawai, dimana dalam diri pegawai akan termotivasi dan timbul rasa percaya diri yang akan menimbulkan suatu semangat dalam bekerja. Motivasi yang tumbuh dari dalam diri pegawai yang tinggi akan meningkatkan kinerja serta kepuasan kerja dalam menyelesaikan suatu pekerjaannya. Selain itu motivasi dapat timbul juga dari orang lain, rekan kerja, atasan bahkan bisa juga dari bawahannya. Semakin tinggi motivasi kerja pegawai dalam menyelesaikan pekerjaannya maka akan meningkatkan kinerja dan prestasi kerja untuk mencapai tujuan organisasi yang efektif dan efisien. Prestasi kerja yang meningkat berarti bahwa kualitas kerja pegawai mengalami peningkatan, sehingga dengan kemampuan pegawai yang meningkat diharapkan pegawai dapat menyelesaikan tugas, pokok, dan fungsi (Tupoksi) dengan baik.

\section{Pengaruh antara Pendidikan dan Pelatihan terhadap Kinerja Karyawan}

Agar setiap karyawan dapat memiliki kinerja yang baik, maka sudah seharusnya setiap perusahaan memberikan pendidikan dan pelatihan kepada setiap karyawannya, minimal pekerjaan yang menjadi tanggungjawabnya. Dengan pendidikan dan pelatihan yang diberikan oleh perusahaan kepada karyawan, maka akan dapat meningkatkan kemampuan karyawan menyelesaikan pekerjaan sehingga akan dapat meningkatkan prestasi kerja karyawan.

Pendidikan dengan berbagai programny mernpunyai peranan penting dalam proses memperoleh dan meningkatkan kualitas kemampuan professional individu. Melalui pendidikan seseorang dipersiapkan untuk memiliki bekal agar siap mengetahui, mengenal dan mengembangkan metode berpikir secara sistematik agar dapat memecahkan masalah yang akan dihadapi dalam kehidupan dikemudian hari (Sedarmayanti, 2001:97). Bernardin \& Russell dalam Gomes (2000) menyatakan bahwa Pelatihan adalah setiap usaha untuk memperbaiki kinerja pekerja pada pekerjaan tertentu yang sedang menjadi tanggung jawabnya,atau satu pekerjaan yang ada kaitannya dengan pekerjaannya, pelatihan lebih berkaitan dengan peningkatan keterampilan.

Penelitian yang dilakukan Ramya (2016) mempelajari pengaruh pelatihan terhadap kinerja karyawan dan menyebutkan bahwa pelatihan memainkan peran penting dalam membangun kompetensi karyawan baru untuk melakukan perkerjaan mereka dengan cara yang efektif. Program pelatihan adalah stimulan yang dibutuhkan pekerja untuk meningkatkan kinerja dan kemampuan karyawan, yang mampu meningkatkan produktivitas organisasi. Hasil penelitian Sunaryo (2016) terhadap Karyawan di PT. Perkebunan Nusantara III (Persero) Medan berkesimpulan bahwa Pendidikan dan Penempatan Kerja Karyawan berpengaruh terhadap Kinerja. Hasil Pendidikan dan Penempatan Kerja Karyawan mempengaruhi kinerja karyawan sebesar 43.7\%. Kemudian ada penelitian dari Onyango dan M.Wanyoike (2014) hasil dari penelitiannya menunjukkan bahwa ada hubungan positif yang kuat antara pelatihan karyawan dan kinerja. Hal ini terbukti dari hasil uji data bahwa penyusun utama didalam skema pemberian gaji (reward) didasarkan pada sistem penilaian yang ditetapkan oleh perusahaan sesuai dengan tingkat pendidikan atau pengalaman karyawan. Penelitian selanjutnya oleh Athar (2015) bahwa melalui pelatihan, karyawan dapat meningkatkan keterampilan dan kemampuan karyawan. Melalui pelatihan karyawan belajar untuk bekerja dalam tim dengan integritas. 


\section{Pengaruh antara Pengembangan Karir terhadap Kinerja Karyawan}

Penelitian dari Erni Widiastuti (2015) berjudul "Pengaruh Pengembangan Karier dan Kondisi Pekerjaan Terhadap Kepuasan Kerja serta dampaknya terhadap Kinerja Pegawai pada Kantor Badan Pelayanan Perizinan Terpadu Kabupaten Sukoharjo", menyatakan pengembangan karier mempunyai pengaruh positif yang signifikan secara langsung dan terhadap kepuasan kerja. Demikian juga, pengembangan karier mempunyai pengaruh positif yang signifikan secara tidak langsung terhadap kinerja kerja.

Menurut Furtwengler (2002) dalam Syanputri (2009: 16) Kinerja pegawai yang optimal dapat tercapai dengan adanya kepuasan kerja pegawai. Seseorang dapat mengembangkan kariernya melalui kenaikan jabatan. Pengembangan karier yang dapat membentuk kepuasan kerja didasarkan pada azas prestasi kerja dan harus bersifat terbuka dan jelas.

Oleh karena itu, salah satu upaya untuk meningkatkan kerja pegawai adalah melalui pengembangan karir, mengingat pengembangan karir akan menimbulkan gairah dalam bekerja dan apabila seorang pegawai merasa semangat dalam bekerja pada akhirnya akan menunjukkan kinerja ang optimal. Oleh karena itu, dalam pengertian tersebut pengembangan karir ecara tidak langsung memiliki hubungan dengan peningkatan kinerja pegawai. Untuk menjelaskan teori tentang pengembangan karir, Kuswadi (2004:33) mengemukakan bahwa: "Pegawai akan menghasilkan kinerja yang baik apabila mereka memiliki motivasi pribadi yang tinggi, setiap motif ditandai dengan keinginan yang kuat untuk mencapai jenis target tertentu, misalnya pengembangan karir". Seperti yang digambarkan di bawah ini:

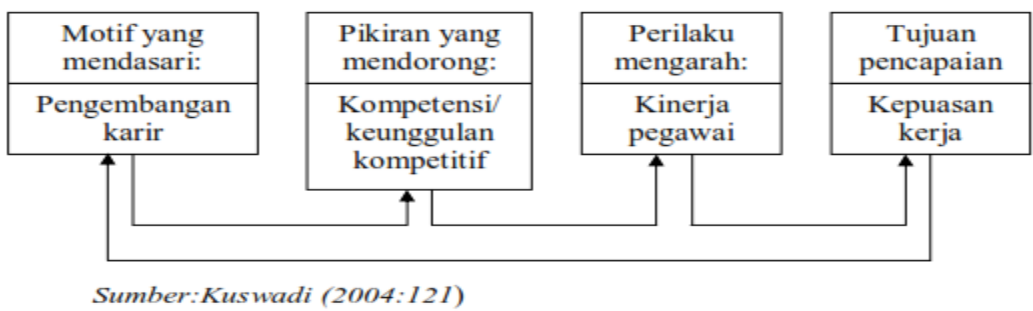

Gambar 1 Hubungan Elemen yang Mendorong Pencapaian Goal State

Dengan adanya pengembangan karir dan dilaksanakan dengan baik, maka setiap pegawai akan berupaya untuk mencapai kinerja yang sebaik-baiknya, sehingga pada gilirannya akan mempunyai kesempatan untuk mengembangkan karirnya yang pada akhirnya cepat atau lambat akan sangat mendukung dalam proses pencapaian tujuan organisasi secara berdaya guna dan berhasil guna. Oleh karena itu, secara keseluruhan bahwa pengembangan karir baik langsung maupun tidak langsung berhubungan dengan peningkatan kinerja seorang pegawai. Keadaan tersebut jelas menuntut peran dan tanggung jawab pimpinan organisasi untuk memberikan kesempatan kepada para pegawai dalam mengembangkan karirnya melalui cara-cara yang memungkinkan, sehingga secara otomatis pegawai merasa puas dalam bekerja dan bersedia untuk menampilkan prestasi kerja yang sangat optimal.

Berdasarkan teori-teori yang telah diuraikan sebelumnya, maka kerangka pemikiran dapat digambarkan dengan adanya hubungan antar variabel bebas yang berpengaruh pada variabel tak bebas, sebagaimana ditunjukkan dalam gambar 2. Untuk analisis ini digunakan pendekatan analisis jalur.

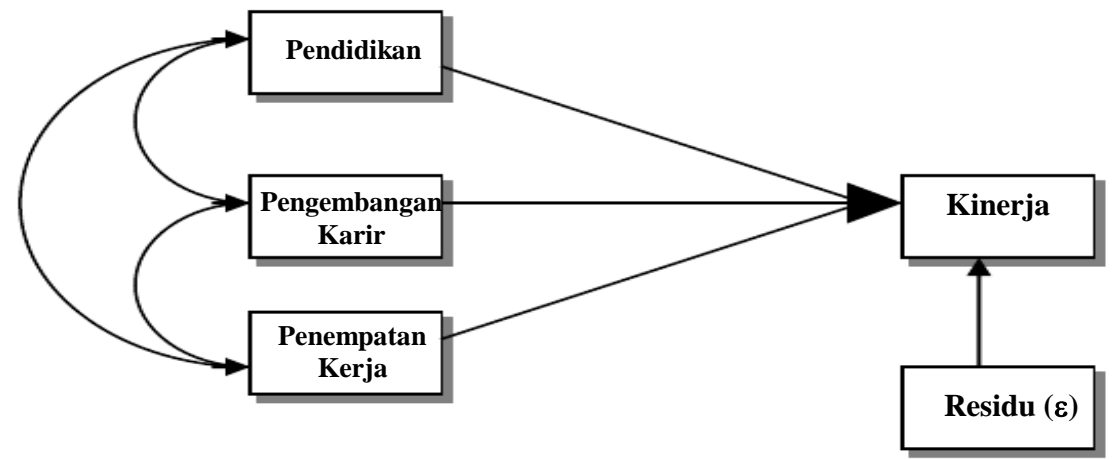

Gambar. 2.2 Kerangka Pemikiran

\section{Metode Penelitian (Methodology)}

Dalam penelitian ini peneliti menggunakan jenis penelitian kuantitatif yaitu melukiskan keadaan yang sebenarnya guna memperoleh fakta yang akan diolah menjadi data, kemudian diolah lebih lanjut untuk 
mendapatkan kesimpulan. Metode penelitian yang digunakan adalah penelitian descriptive dan verificative. Penelitian descriptive merupakan penelitian yang bertujuan untuk memperoleh deskripsi tentang Diklat, pengembangan karier, penempatan jabatan dan kinerja karyawan di Universitas Almuslim Bireuen. Sedangkan penelitian verifikative pada dasarnya ingin menguji kebenaran dari suatu hipotesis yang dilaksanakan melalui pengumpulan data di lapangan (Arikunto, $2006: 11$ ). Sampel yang diteliti adalah semua karyawan Universitas Almuslim sejumlah 158 karyawan.

Desain penelitian ini adalah terdiri dari 3 (tiga) variabel independen yaitu Diklat $\left(\mathrm{X}_{1}\right)$, Pengembangan karier $\left(\mathrm{X}_{2}\right)$ dan Penempatan jabatan kerja $\left(\mathrm{X}_{3}\right)$ terhadap variabel Dependen yaitu Kinerja $(\mathrm{Y})$. Dngan operasional variabel penelitian dinyatakan dalam tabel berikut:

Tabel 1. Definisi Operasionalisasi Variabel

\begin{tabular}{|c|c|c|}
\hline Variabel & Dimensi & Indikator \\
\hline $\begin{array}{l}\text { Pendidikan dan Pelatihan (X1) } \\
\text { Program pendidikan dan pelatihan merupakan sarana pembinaan dan } \\
\text { pengembangan karir, melalui keikut sertaan dalam program pendidikan } \\
\text { dan pelatihan, pegawai terpilih secara sadar dan berencana dipersiapkan } \\
\text { oleh organisasinya untuk menerima tanggung jawab pekerjaan yang } \\
\text { berbeda (rotasi) dan atau kedudukan /jabatan yang lebih tinggi } \\
\text { (promosi) pada waktu yang akan dating (future oriented), dan } \\
\text { karenanya program pendidikan dan pelatihan merupakan salah satu } \\
\text { inves tasi surnber daya manusia (human invesment) yang sangat } \\
\text { berharga bagi setiap organisasi pemerintah (LAN, 2002). }\end{array}$ & $\begin{array}{l}\text { 1. Instruktur, Peserta, } \\
\text { 2. Materi (bahan), } \\
\text { 3. Metode, } \\
\text { 4. Tujuan pelatihan, } \\
\text { 5. Lingkungan yang } \\
\text { menunjang } \\
\text { Veithzal Rivai } \\
\text { (2011:225-226), }\end{array}$ & $\begin{array}{l}\text { 1) Karir karyawan, } \\
\text { 2) Pengetahuan, } \\
\text { 3) Pendidikan sesuai } \\
\quad \text { kebutuhan, } \\
\text { 4) Sikap dan } \\
\text { 5) Perilaku. } \\
\text { Veithzal Rivai } \\
(2005: 256)\end{array}$ \\
\hline $\begin{array}{l}\text { Pengembangan Karir (X2) } \\
\text { Pengembangan karir adalah kegiatan yang dilakukan untuk meningkatkan } \\
\text { kemam-puan dalam rangka mencapai suatu rencana karir (Handoko, } \\
\text { 2003). } \\
\text { Pengembangan karir adalah suatu rangkaian kegiatan kerja yang terpisah } \\
\text { tetapi berkaitan, yang memberikan kesinambungan dan arti dalam } \\
\text { kehidupan seseorang } \\
\text { Flippo (2001) }\end{array}$ & $\begin{array}{l}\text { 1. Alur /Jalur karir, } \\
\text { 2. Tujuan karir, } \\
\text { 3. Perencanaan karir, } \\
\text { 4. Pengembangan karir } \\
\text { Mangkuprawira (2002), }\end{array}$ & $\begin{array}{ll}\text { 1. } & \text { Peningkatan } \\
& \text { Kemampuan } \\
\text { 2. } & \text { Kepuasan kerja } \\
\text { 3. } & \text { Sikap } \\
\text { 4. } & \text { Perilaku karya-wan } \\
& \text { terhadap } \\
& \text { pekerjaanya } \\
\text { Burlian (2005) }\end{array}$ \\
\hline $\begin{array}{l}\text { Penempatan Jabatan Kerja (X3) } \\
\text { Penempatan kerja pada karyawan berarti mengalo-kasikan para karyawan } \\
\text { pada posisi tertentu, hal ini khusus terjadi pada karyawan baru. Kepada } \\
\text { karyawan lama yang telah menduduki jabatan atau pekerjaan termasuk } \\
\text { sasaran fungsi penempatan karyawan dalam arti mempertahankan pada } \\
\text { posisinya atau memindahkan pada posisi yang lain. } \\
\text { Rivai \& Sagala (2009) : }\end{array}$ & $\begin{array}{l}\text { 1) Kinerja Akademik } \\
\text { 2) Pengalaman } \\
\text { 3) Kesehatan Fisik dan } \\
\text { Metal } \\
\text { 4) Status Perkawinan } \\
\text { 5) Usia } \\
\text { (Hasibuan, 2005) }\end{array}$ & $\begin{array}{l}\text { 1) pendidikan, } \\
\text { 2) pengetahuan kerja, } \\
\text { 3) keterampilan kerja, } \\
\text { 4) keahlian } \\
\text { Yuniarsih \& Suwatno } \\
\text { (2016) }\end{array}$ \\
\hline $\begin{array}{l}\text { Kinerja (Y) } \\
\text { Kinerja adalah hasil kerja secara kualitas dan kuantitas yang dicapai oleh } \\
\text { seorang pegawai dalam melaksana-kan tugasnya sesuai dengan tanggung } \\
\text { jawab yang diberikan kepadanya. } \\
\text { Mangkunegara (2007), . } \\
\text { Kinerja adalah hasil kerja yang dapat dicapai oleh seseorang atau } \\
\text { sekelompok orang dalam suatu organisasi, sesuai dengan wewenang dan } \\
\text { tanggung jawab masing-masing, dalam rangka upaya mencapai tujuan } \\
\text { organisasi bersangkutan secara legal, tidak melanggar hukum dan sesuai } \\
\text { dengan moral maupun etika. } \\
\text { Rivai (2006) }\end{array}$ & $\begin{array}{l}\text { 1. Bakat, } \\
\text { 2. Pendidikan,pelatihan, } \\
\text { 3. Pengembangan karir, } \\
\text { 4. Lingkungan dan } \\
\text { fasilitas, } \\
\text { 5. Iklim kerja, } \\
\text { 6. Motivasi dan kemampu- } \\
\text { an hubungan industrial, } \\
\text { 7. Teknologi, } \\
\text { 8. Manajemen, } \\
\text { 9. Kesempatan berprestasi } \\
\text { Suprihanto (2000) }\end{array}$ & $\begin{array}{ll}\text { 1. } & \text { Kuantitas kerja } \\
\text { 2. } & \text { Kualitas kerja } \\
\text { 3. } & \text { Jangka waktu } \\
\text { 4. } & \text { Kerjasama } \\
\text { Mathis dan Jackson } \\
(2002)\end{array}$ \\
\hline
\end{tabular}

Metode analisis data meliputi: pengujian persyaratan analisis dan menguji hipotesis penelitian dengan menggunakan model analisis jalur (Path Analysis). Untuk memperoleh persyaratan analisis, dilakukan uji: asumsi normalitas, linearitas, otokorelasi, dan uji multikolinieritas. Dan menguji hipotesis penelitian dengan menggunakan analisis model jalur (Path Analyis). Pedhazur (1982) dalam Marwan, dkk (2019) mengemukakan asumsi yang harus dipenuhi untuk menggunakan analisis jalur ada lima, yaitu: (1) Hubungan antara variabel dalam model linier, aditivitas tidak ada efek-efek interaksi dan kausal; (2) Semua variabel residu (yang tidak diukur) tidak berkorelasi dengan salah satu variabel yang membangun model; (3) Adanya rekursivitas. Semua anak panah mempunyai satu arah, tidak boleh terjdi pemutaran balik; (4) Variabel yang diukur berskala interval; dan (5) Variabel diukur tanpa kesalahan.

Pemilihan metode analisis jalur menurut Kusnendi, (2005) dan Sarwono, Y. (2007) dalam Amiruddin dan Win (2012:17) dilakukan dengan pertimbangan:

a. Metode ini mampu memberikan kejelasan hubungan dan besaran antar variabel penelitian yang sangat berguna bagi upaya peneliti dalam mengupas berbagai variabel yang diteliti. 
b. Analisis jalur cocok digunakan untuk mengana-lisis hubungan sebab akibat, baik untuk mengetahui pengaruh langsung maupun tidak langsung seperangkat variabel penyebab (variabel eksogen) terhadap set variabel akibat (endogen), baik secara simultan maupun parsial.

c. Analisis jalur cocok untuk sampel yang melebihi atau diatas 100 responden dan data diolah bersifat exploratory serta data dapat diobservasi secara langsung di lapangan.

Alasan menggunakan analisis jalur karena metode ini dapat menganalisis pola hubungan kausal antara variabel dengan tujuan untuk mengetahui pengaruh langsung dan tidak langsung, secara serempak atau bersama-sama dan parsial atau mandiri, beberapa variabel penyebab terhadap sebuah variabel akibat. (Pedhazur, E.J; 1982, dalam Marwan; 2019).

Analisis jalur ini mengikuti pola struktural atau disebut model struktural. Maka model struktural dalam analisis ini adalah sebagai berikut.

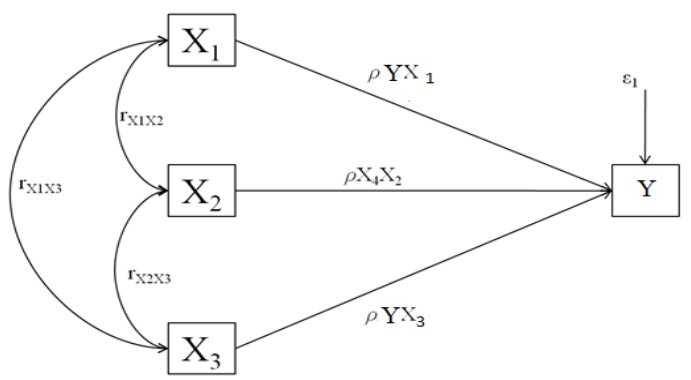

Gambar 1. Kerangka Pemikiran \& Model Teoretis
Keterangan :

$\mathrm{X}_{1}=$ Diklat

$\mathrm{X}_{2}=$ Pengembangan Karier

$\mathrm{X}_{3}=$ Penempatan Karyawan, $\mathrm{Y}=$ Kinerja Karyawan

$\varepsilon=$ Epsilon, yaitu menunjukkan variabel atau faktor residual yang menjelaskan pengaruh variabel lain yang telah teridentifikasi oleh teori, tetapi tidak diteliti atau variabel lainnya yang belum teridenti-fikasi oleh teori, atau muncul sebagai akibat dari kekeliruan pengukuran variabel.

\section{Hasil dan Pembahasan (Results and Discussion)}

\section{Uji Asumsi Klasik}

\section{a). Uji Normalitas}

Uji normalitas data dilakukan untuk menentukan data penelitian tiap-tiap variabel penelitian berdis-tribusi secara normal. Dalam penelitian ini, uji normalitas data dilakukan dengan menggunakan normal probability plot. Hasil Pengujian Normalitas dapat dilihat pada gambar 3.

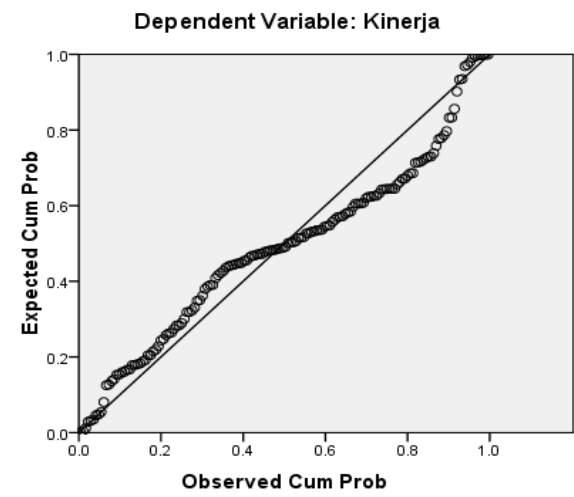

Gambar 3. Uji Normalitas Data

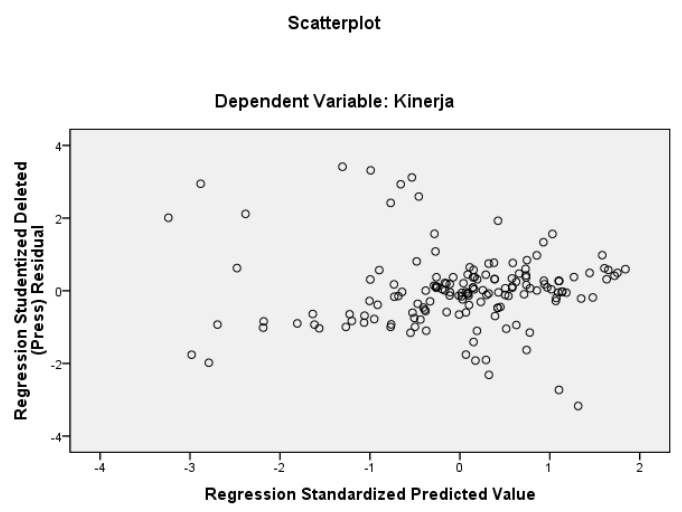

Gambar 4. Uji Heterokedastisitas

Dari grafik kurva normal, dapat disimpulkan bahwa data yang digunakan menunjukkan normal. Santoso (2009:342) menyatakan bahwa jika data menyebar normal di sekitar garis diagonal dan mengikuti arah garis diagonal, maka model regresi memenuhi asumsi normalitas. Uji ini dilakukan untuk mengetahui simetris tidaknya distribusi data.

\section{b). Uji Heterokedastisitas}

Menurut Santoso (2009), heterokedastisitas terjadi bila kesalahan atau residual dari model yang diamati tidak memiliki varian yang konstan dari satu observasi ke observasi lainnya. Deteksi dapat dilakukan dengan analisa grafis, dimana jika terdapat pola tertentu pada scatterplot maka terjadi heterokedastisitas. Uji heterokedatisitas dilakukan untuk mengetahui penyebaran varians gangguan. Hasil pengujian heterokedatisitas data dalam penelitian ini menggunakan alat bantu SPSS dengan mengamati pola pada scatterplot, hasilnya dapat dilihat pada gambar 4 . 
Dari gambar 3 di atas dapat dilihat bahwa titik-titik menyebar secara acak (random) serta tersebar di atas maupun di bawah angka 0 pada sumbu Y, sehingga dapat disimpulkan bahwa tidak terjadi heterokedastisitas pada model regresi dan layak dipakai untuk memprediksi keputusan memilih berdasarkan masukan dari variabel bebasnya.

\section{c). Uji Multikolinearitas}

Mmenurut Santoso (2009) suatu model regresi dikatakan bebas dari masalah tersebut jika nilai Variance Inflation Factor (VIF) dan Tolerance adalah : a.Mempunyai nilai Variance Inflation Factor dibawah 10 , b.Mempunyai angka Tolerance diatas 0 mendekati 1., c. Besaran korelasi antar variabel independen haruslah lemah, dibawah 0,5. Uji multikollinieritas dilakukan untuk mengetahui ada tidaknya korelasi antar varibel bebas yang disebut dengan multikolonieritas. Hasil pengujian multikollinieritas data dalam penelitian ini menggunakan alat bantu SPSS, hasilnya dapat dilihat pada tabel 2, berikut :

Tabel 2. Hasil Uji Multikolinearitas

\begin{tabular}{|l|c|c|}
\hline \multicolumn{2}{|c|}{ Collinearity Statistics } \\
\hline Diklat & Tolerance & VIF \\
\hline Pengembangan Karir & 0.294 & 3.404 \\
\hline Penempatan Jabatan & 0.423 & 2.366 \\
\hline
\end{tabular}

Dari tabel 2, dapat dilihat bahwa variabel bebas yang memiliki nilai Variance Inflation Factor dibawah 10 dan mempunyai angka Tolerance diatas 0. Jadi dapat disimpulkan bahwa tidak ada multikollinieritas antar variabel bebas dalam model regresi.

\section{Hasil Path Analysis}

\section{a). Uji Model Secara Simultan}

Dalam penelitian ini model analisis dengan analisi jalur yang menentukan pengaruh variabel Pendidikan dan Pelatihan $\left(\mathrm{X}_{1}\right)$, Pengembangan Karier $\left(\mathrm{X}_{2}\right)$ dan Penempatan Jabatan $\left(\mathrm{X}_{3}\right)$ terhadap Kinerja karyawan Universitas Almuslim Bireuen (Y). Dengan model $Y=f(X 1, X 2, X 3)=\rho_{1} X_{1}+\rho_{2} X_{2}+\rho_{3} X_{3}+$ e. Adapun pembuktian hipotesis secara simultan (keseluruhan) dapat dilihat pada tabel 3 berikut ini:

Tabel 3. Uji Model Analisis Secara Simultan

\begin{tabular}{|l|c|c|c|c|c|}
\hline \multicolumn{1}{|c|}{ Model } & Sum of Squares & df & Mean Square & F & Sig. \\
\hline Regression & 4381.629 & 3 & 1460.543 & 66.549 & $.000^{\mathrm{a}}$ \\
\hline Residual & 3379.798 & 154 & 21.947 & & \\
\hline Total & 7761.427 & 157 & & & \\
\hline
\end{tabular}

Sumber: Data Primer, 2020 (hasil olahan)

Berdasarkan hasil uji $\mathrm{F}$ diperoleh nilai $\mathrm{F}_{\text {hitung }}$ sebesar 66,549, dan signifikansi pada 0.000. Dengan demikian dapat disimpulkan bahwa probabilitas dalam penelitian ini lebih kecil dari 0,05\% maka variabel Pendidikan dan Pelatihan $\left(\mathrm{X}_{1}\right)$, Pengembangan Karier $\left(\mathrm{X}_{2}\right)$ dan Penempatan Jabatan $\left(\mathrm{X}_{3}\right)$ secara simultan berpengaruh signifikan terhadap Kinerja karyawan Universitas Almuslim Bireuen (Y).

\section{b). Penentuan Koefisien Korelasi (r) dan Koefisien Jalur (P)}

Selanjutnya dilakukan pengujian hipotesis yang diajukan selanjutnya diuji untuk menjawab masalah penelitian yang dirumuskan. Kemudian dilanjutkan dengan pengujian model yang dihipotesiskan, menentukan pengaruh langsung dan tidak langsung, selanjutnya pembahasan hasil penelitian.

Pertama dilakukan taksiran nilai kausalitas antar variabel eksogen $\left(\mathrm{X}_{1}, \mathrm{X}_{2}, \mathrm{X}_{3}\right)$ yang hasilnya disajikan dalam Tabel 4. Dan terbukti terdapat hubungan kausalitas antar variabel independen (eksogen).

Tabel 4. Hubungan Kausal Antar Variabel Bebas (Eksogenus)

\begin{tabular}{|l|l|c|c|c|}
\hline & & Diklat & Pengembangan Karier & Penempatan Jabatan \\
\hline \multirow{2}{*}{ Diklat } & Pearson Correlation & 1 & $.715^{\pi_{*}}$ & $.825^{\text {** }}$ \\
\cline { 2 - 5 } & Sig. (2-tailed) & & .000 & .000 \\
\hline Pengembangan Karier & Pearson Correlation & & 1 & $.735^{* \pi}$ \\
\cline { 2 - 5 } & Sig. (2-tailed) & & & .000 \\
\hline
\end{tabular}

**. Correlation is significant at the 0.01 level (2-tailed). 
Lalu ditaksir nilai koefisien jalur antar variabel eksogen $\left(\mathrm{X}_{1}, \mathrm{X}_{2}, \mathrm{X}_{3}\right)$ terhadap variabel endogen $(\mathrm{Y})$, dengan hasilnya sebagai berikut (Tabel 5):

Tabel 5. Taksiran Koefisien Jalur (Beta)

\begin{tabular}{|l|l|c|c|c|}
\hline \multirow{2}{*}{ Model } & Standardized Coefficients & \multirow{2}{*}{ t } & \multirow{2}{*}{ Sig. } \\
\cline { 3 - 3 } & Beta $=\rho$ & & \\
\hline \multirow{3}{*}{ Variabel } & Diklat & 0.304 & 3.102 & 0.002 \\
\cline { 2 - 3 } & Pengemb.Karier & 0.309 & 3.773 & 0.000 \\
\cline { 2 - 3 } & Penempatan jabatan & 0.208 & 2.057 & 0.041 \\
\hline
\end{tabular}

Sumber: Data Primer, 20120 (hasil olahan SPSS)

Atas dasar nilai statistik t, pada tabel 5 menunujukkan bahwa ketiga koefsiien jalur dinyatakan signifikansi pada taraf uji 5\%. Berdasarkan hal diatas yakni hubungan antar variabel eksogen, dan nilai koefisien jalur $(\rho)$, maka model kausal yang dibentuk secara teoritik diperoleh diagram jalur seperti gambar 4 , berikut;
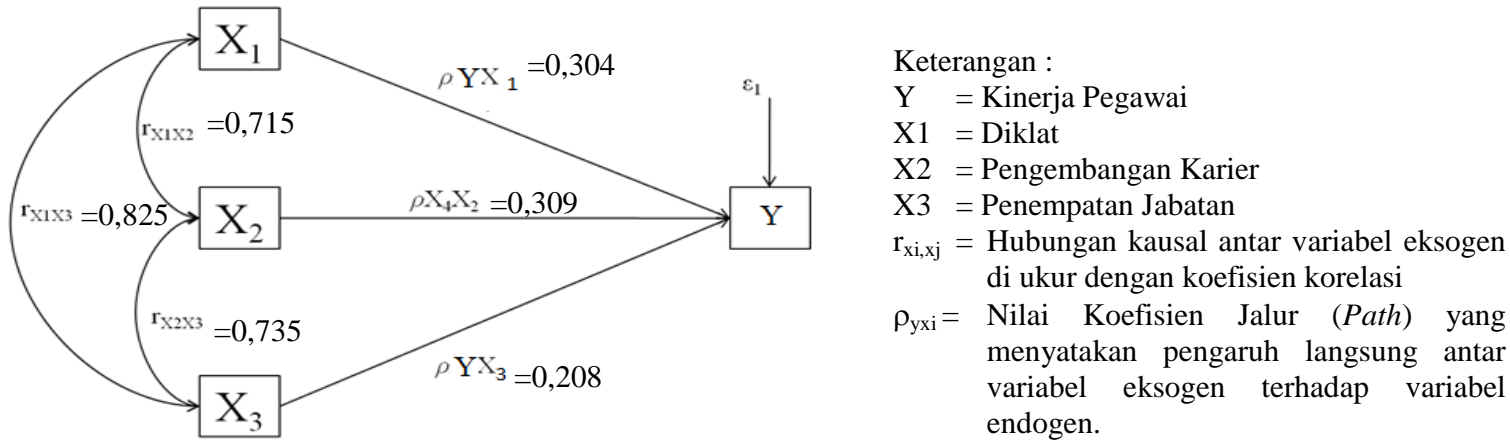

Gambar 5. Diagram Jalur Penelitian

\section{c. Analisis Pengaruh Diklat terhadap Kinerja karyawan}

Besarnya pengaruh langsung Diklat $\left(\mathrm{X}_{1}\right)$ terhadap Kinerja karyawan $(\mathrm{Y})$, dinyatakan dengan besaran koefisien jalur $\left(\rho_{y \times 1}=0,304\right)$, Sehingga besarnya pengaruh langsung ini adalah: 9,24\%

Besarnya pengaruh tak langsung Diklat $\left(\mathrm{X}_{1}\right)$ terhadap Kinerja $(\mathrm{Y})$, karena adanya hubungan kausal diklat dengan $\mathrm{X}_{2}$ (pengembangan karier) dan $\mathrm{X}_{3}$ (Penempatan jabatan), dinyatakan dengan besaran koefisien jalur, dan koefisien korelasi dari hubungan antar variabel dimaksud, yaitu:

- Pengaruh Diklat $\left(\mathrm{X}_{1}\right)$ dengan Pengembangan karier $\left(\mathrm{X}_{2}\right)$ terhadap Kinerja $(\mathrm{Y})$ sebesar 6,72\%

- Pengaruh Diklat $\left(\mathrm{X}_{1}\right)$ dengan Penempatan jabatan $\left(\mathrm{X}_{3}\right)$ terhadap Kinerja $(\mathrm{Y})$ sebesar5,22\%

- Sehingga pengaruh total variabel Diklat $\left(\mathrm{X}_{1}\right)$ terhadap Kinerja karyawan $(\mathrm{Y})$, yakni : 21,18\%.

Hasil ini juga senada dengan hasil penelitian yang dilakukan oleh Enrich C, Simanungkalit, (2010) tentang Hubungan Pendidikan, pengembangan karir dan Penempatan jabatan, kinerja, pola karir, dan perencanaan karir pegawai di Kantor Regional VI Badan Kepegawaian Negara Medan. Hasil penelitian menunjukkan pendidikan dan pengembangan karir serta penempatan jabatan secara serempak berpengaruh sangat sangat signifikan terhadap kinerja pegawai dan secara parsial variabel pendidikan berpengaruh lebih dominan dari pada variabel pengembangan karir dan Penempatan jabatan.

\section{d. Analisis Pengaruh Variabel Pengembangan Karier terhadap Kinerja karyawan}

Besarnya pengaruh langsung Pengembangan Karier $\left(\mathrm{X}_{2}\right)$ terhadap Kinerja karyawan $(\mathrm{Y})$, dinyatakan dengan besaran koefisien jalur ( $\left.\rho_{\mathrm{yx} 2}=0,309\right)$, sehingga pengaruh langsung: $(0,309)^{2} \times 100 \%=9,55 \%$.

Besarnya pengaruh tak langsung Pengembangan Karier $\left(\mathrm{X}_{2}\right)$ terhadap Kinerja $(\mathrm{Y})$, karena adanya hubungan kausal Pengembangan Karier $\left(\mathrm{X}_{2}\right)$ dengan diklat $\left(\mathrm{X}_{1}\right)$ dan Penempatan jabatan $\left(\mathrm{X}_{3}\right)$, dinyatakan dengan besaran koefisien jalur, dan koefisien korelasi dari hubungan antar variabel dimaksud, yaitu:

- Pengaruh Pengembangan Karier $\left(\mathrm{X}_{2}\right)$ dengan Diklat $\left(\mathrm{X}_{1}\right)$ terhadap Kinerja $(\mathrm{Y})$ sebesar 6,72\%

- Pengaruh Pengembangan Karier $\left(\mathrm{X}_{2}\right)$ dengan Penempatan jabatan $\left(\mathrm{X}_{3}\right)$ sebesar 4,72\%

- Sehingga pengaruh total Pengembangan Karier $\left(\mathrm{X}_{2}\right)$ terhadap Kinerja karyawan $(Y)$, yakni : 20,99\%.

Hasil ini juga senada dengan hasil penelitian yang dilakukan oleh Tenny, Puspitasari, Abdul Djali, dan Joni Pambelum (2015), tentang Pengaruh Pengembangan Karier, Penempatan Jabatan dan Motivasi terhadap Prestasi Kerja Pegawai. Dan hasilnya terbukti bahwa Pengembangan Karier baik secara parsial, maupun dengan faktor penempatan jabatan dan motivasi kerja pegawai berpengaruh terhadap prestasi/kinerja. 


\section{e. Analisis Pengaruh Variabel Penempatan Jabatan terhadap Kinerja karyawan}

Besarnya pengaruh langsung Penempatan jabatan $\left(\mathrm{X}_{3}\right)$ terhadap Kinerja karyawan $(\mathrm{Y})$, dinyatakan dengan besaran koefisien jalur $\left(\rho_{\mathrm{yx} 2}=0,208\right)$, sehingga besarnya pengaruh langsung: $(0,208)^{2} \mathrm{x} 100 \%=4,33 \%$.

Besarnya pengaruh tak langsung Penempatan jabatan $\left(\mathrm{X}_{3}\right)$ terhadap Kinerja $(\mathrm{Y})$, karena adanya hubungan kausal Penempatan jabatan $\left(\mathrm{X}_{3}\right)$ dengan Pengembangan Karier $\left(\mathrm{X}_{2}\right)$ dengan diklat $\left(\mathrm{X}_{1}\right)$, dinyatakan dengan besaran koefisien jalur, dan koefisien korelasi dari hubungan antar variabel dimaksud, yaitu:

- Pengaruh Penempatan jabatan $\left(\mathrm{X}_{3}\right)$ dengan Diklat $\left(\mathrm{X}_{1}\right)$ terhadap Kinerja $(\mathrm{Y})$ sebesar 5,22\%

- Pengaruh Penempatan jabatan $\left(X_{3}\right)$ dengan Pengembangan Karier $\left(X_{2}\right)$ terhadap Kinerja $(Y)=4,72 \%$

- Sehingga pengaruh total Penempatan jabatan $\left(\mathrm{X}_{3}\right)$ terhadap Kinerja karyawan $(\mathrm{Y})$, yakni : 14,27 \%.

Hasil ini juga senada dengan hasil penelitian yang dilakukan oleh Sunaryo (2016) dengan judul penelitian Pengaruh Pendidikan dan Penempatan Kerja terhadap Kinerja Karyawan di PTPN III Medan. Hasilnya membuktikan terdapat pengaruh kedua variable baik pendidikan dan penempatan kerja terhadap kinerja. Pendidikan dan Penempatan Kerja Karyawan dalam menjelaskan kinerja adalah sebesar 43.7\%.

\section{f. Korelasi dan Determinasi}

Untuk meyakinkan adanya keterkaitan antar variabel yang diteliti, juga di dukung dari nilai statistik koefisien korelasi $(\mathrm{R})$ dan koefisien determinasi $\left(\mathrm{R}^{2}\right)$. Maka analisis koefisien korelasi dan determinasi variabel bebas $(\mathrm{X})$ dengan variabel terikat $(\mathrm{Y})$ yang dapat dilihat dari tabel berikut:

Tabel 6. Koeisien Korelasi Simultan

\begin{tabular}{|c|c|c|c|}
\hline $\mathrm{R}$ & R Square & Adjusted R Square & Std. Error of Estimate \\
\hline $0.751^{\mathrm{a}}$ & 0.565 & 0.556 & 4.68474 \\
\hline
\end{tabular}

Hasil analisis koefisien korelasi antara Diklat, Pengembangan karier dan Penempatan jabatan karyawan terhadap Kinerja karyawan diperoleh $R$ sebesar 0,751 menjelaskan hubungan antara Diklat, Pengembangan karier dan Penempatan jabatan karyawan terhadap Kinerja karyawan memiliki keeratan yang cukup tinggi, dan berhubungan secara linier, dengan derajat hubungannya sebesar 0,751 .

\section{Simpulan dan Saran (Conclusion and Suggestion)}

\section{Simpulan (Conclusion)}

Berdasarkan penelitian ini, maka dapat disimpulkan beberapa hasil dari keseluruhan dalam penelitian yaitu sebagai berikut :

1. Hasil analisis, menunjukkan adanya pengaruh faktor Pendidikan dan Pelatihan terhadap Kinerja karyawan Universitas Almuslim, yakni sebesar 21,18\%.

2. Hasil analisis data juga membuktikan adanya pengaruh faktor Pengembangan Karier terhadap Kinerja karyawan Universitas Almuslim, yakni sebesar 20,99\%.

3. Dan dari hasil analisis selanjutnya, menunjukkan adanya pengaruh faktor Penempatan Jabatan karyawan terhadap Kinerja karyawan Universitas Almuslim, yakni sebesar 14,27 \%.

4. Hasil analisis deskriptif, menemukan bahwa, a). Pendidikan dan Pelatihan yang dicapai dan dirasakan karyawan dalam menunjang kinerja adalah sebesar 73,76 persen. Sedangkan penilaian karyawan pelaksanaan pengembangan karier bagi karyawan di lingkungan Universitas Almuslim, baru mencapai $75 \%$. Dan masalah penempatan jabatan kerja karyawan memang perlu dan penting, pelaksanaannya menurut persepsi karyawan sudah mencapai 76,09\%.

\section{Saran (Suggestion)}

1. Kebijakan Pengembangan karir bagi karyawan pada Universitas Almuslim Bireuen Aceh hendaknya juga memperhatikan faktor masa kerja dan kebutuhan organisasi sehingga setiap karyawan punya kesempatan dalam menduduki jabatan dengan ketentuan memenuhi persyaratan yang dibutuhkan.

2. Pemberian kesempatan pada semua karyawan untuk dapat mengikuti pendidikan dan pelatihan serta promosi hendaknya dilakukan berdasarkan tingkat keahlian, pendidikan, loyalitas dan pengalaman kerja karyawan agar karyawan dapat mempersiapkan dan merencanakan karir mereka dengan baik sehingga diharapkan karyawan dapat termotivasi dan akan bekerja dengan lebih baik lagi dan dana yang telah dialokasikan untuk kegiatan pendidikan dan pelatihan setiap tahunnya benar-benar terealisasi sesuai dengan kebutuhan. 


\section{DAFTAR PUSTAKA (References)}

1) Agustini, F. (2011). Manajemen Sumber Daya Lanjutan. Medan: Madenatera.

2) Amiruddin dan Win, 2010. Model Peningkatan Kualitas Sdm Penduduk Usia Kerja Yang Unggul Professional Dan Islami, Jurnal ekonomika Universitas Almuslim Bireuen - Aceh, Vol.1 No.1 Maret 2010

3) Amiruddin Idris dan Win Konadi, 2012. pengaruh regulasi dan ketersediaan anggaran terhadap kinerja pelayanan aparatur SKPD dan implikasinya pada kualitas pelayanan publik di Provinsi Aceh, Jurnal Kebangsaan, Vol 1 No 1, Januari 2012. ISSN: 2089-5917

4) Athar,Rida,et.al. (2015). Impact of Training on Employee Performance (Banking Sector Karachi).IOSR.Journal of Business and Management.Vol 17,Issue 11,pp 58-67.

5) Erni Widiastuti (2015), Pengaruh Pengembangan Karier Dan Kondisi Pekerjaan Terhadap Kepuasan Kerja Serta Dampaknya Terhadap Kinerja Pegawai Pada Kantor Badan Pelayanan Perizinan Terpadu Kabupaten Sukoharjo, Jurnal Manajemen Sumber Daya Manusia Vol. 9 No. 2 Desember 2015: 164 - 170.

6) Enrich C, Simanungkalit, (2010), Hubungan Pendidikan, pengembangan karir dan Penempatan jabatan, kinerja, pola karir, dan perencanaan karir pegawai di Kantor Regional VI Badan Kepegawaian Negara Medan, Penelitian

7) Flippo, Edwin. P. (2001). Manajemen Personalia dan Sumber Daya Manusia. Edisi keenam, Jakarta : Erlangga

8) Gomes, F. C. (2000). Manajemen Sumber Daya Manusia. Andi Offset. Yogyakarta

9) Hasibuan, Malayu, SP., (2005), Manajemen Sumber Daya Manusia, Cetakan Ke 2, Penerbit Bumi Aksara, Jakarta

10) Hasibuan, Malayu. (2002), Manajemen Sumber Daya Manusia . Bumi Aksara. Jakarta

11) Handoko, T. Hani. (2003), Manajemen Personalia dan Sumber Daya Manusia, Yogyakarta, BPFE-Yogyakarta

12) Kuswadi. (2004). Cara Mengukur Kepuasan Karyawan. Jakarta: PT. Elex Media Komputindo

13) Lembaga Administrasi Negara (LAN) Republik Indonesia (2002), "Badan Pengawasan Keuangan dan Pembangunan (BPKP), Pengukuran Kinerja Instansi Pemerintah: Modul Sosialisasi Sistem Akuntabilitas Kinerja Institut Pemerintah, Lembaga Administrasi Negara (LAN) RI.

14) Mangkunegara, A.A. Anwar Prabu (2000). Manajemen Sumber Daya Manusia Perusahaan, Penerbit Remaja Rosdakarya, Bandung

15) Mangkunegara. A.A. Anwar Prabu, (2011). Manajemen Sumber Daya Manusia. Perusahaan. Bandung: PT. Remaja Rosdakarya

16) Marwan Hamid, Ibrahim Sufi, Win Konadi, dan Yusrizal Akmal, 2019. Analisis Jalur Dan Aplikasi Spss Versi 25, Edisi Pertama

17) Mathis L., Robert And Jackson, H. John (2006), Human Resource Management, Edisi Kesepuluh, Penerbit Salemba Empat, Jakarta

18) Muhammad Burlian (2005), Pengaruh pengembangan karir terhadap kinerja pegawai balai karantina ikan Polonia Medan. Tesis, Universitas Sumatera Utara

19) Nasution. (2002), Metode Research : Penelitian Ilmiah, Jakarta, PT. Bumi Aksara.

20) Notoatmodjo, Soekidjo (2003), Pendidikan dan Perilaku Kesehatan, Rineka Cipta, Jakarta

21) Onyango, James Watta. (2014). Effect of Training on Employee performance : A Survey of Health workers in siaya County, Kenya.European Journal of Material Sciences.Vol1,pp.11-15.

22) Puspitasari, T., Djali, A., \& Pambelum, J. (2015). Pengaruh Pengembangan Karier , Penempatan Jabatan Dan Motivasi Terhadap Prestasi Kerja Pegawai. JSM (Jurnal Sains Manajemen), IV(1), 65-76.

23) Ramya. (2016). The Effect Training of Employee Performance.International Journal of Scientific Research and Modern Education, vol I, issue I, pp. 2455-5630

24) Rivai, V., \& Sagala, E. J. (2009). Manajemen Sumber Daya Manusia untuk Perusahaandari Teori ke Praktik. Jakarta: PT. Raja Grafindo Persada.

25) Rivai Vehitzal, (2005), Manajemen Sumber Daya Manusia Untuk Perusahaan Dari Teori Ke Praktik, Muria Kencana, Jakarta

26) Saksono Sastrohadiwiryo, Siswanto. (2003). Manajemen Tenaga Kerja Indonesia (Pendekatan Administratif dan Operasional). Jakarta: PT Bumi Aksara.

27) Sastrohadiwiryo, Siswanto, B., (2002), Manajemen Tenaga Kerja Indonesia, Penerbit Bumi Aksara, Jakarta

28) Sedarmayanti. (2001). Sumber Daya Manusia dan Produktivitas Kerja. Bandung: Mandar Maju

29) Singgih Santoso. 2009, Panduan Lengkap Menguasai Statistik Dengan SPSS. Jakarta: PT.

30) Sunaryo (2016), Pengaruh Pendidikan Dan Penempatan Kerja Terhadap Kinerja Karyawan Di PTPN III Medan, Jurnal Ilmiah Manajemen dan Bisnis Vol. 17, No. 01, April 2016

31) Suprihanto. (2000), Manajemen Sumber Daya Manusia. Universitas Terbuka,. Karunika, Jakarta 
32) Syanputri, Firstri, (2009), Analisis Pengaruh Kepuasan Kerja terhadap Kinerja Tenaga Kependidikan (Studi Kasus: Sembilan Fakultas Institut Pertanian Bogor, Darmaga Bogor), Skripsi, Fakultas Ekonomi dan Manajemen, Institut Pertanian Bogor, Bandung.

33) Thoha, Miftah. 2008. Manajemen Kepegawaian Sipil di Indonesia. Kencana Prenada Media Group. Jakarta.

34) Umar, Hamalik.. (2000). Evaluasi Kurikulum. Bandung: PT Remaja Rosdakarya

35) Yuniarsih, T., \& Suwatno. (2016). Manajemen Sumber Daya Manusia Teori, Aplikasi dan Isu Penelitian (Kelima). Bandung: Alfabeta 